\title{
Indonesia dan Responsibility To Protect Etnis Muslim Rohingnya Myanmar
}

\author{
Hendra Maujana Saragih \\ Hubungan Internasional FISIP Universitas Nasional \\ hendramaujana@gmail.com
}

\begin{abstract}
This paper aims to identify and describe the Rohingya Myanmar Muslim ethnic conflicts over the past five years which can thus be gained informative findings that can provide concrete solutions to the end of the conflict in Myanmar and to describe the Indonesian response in resolving this ethnic conflict. This research uses the Concept of Responsibility to Protect (R2P), the Concept of Human Rights Violation in which the Rohingnya Muslim minority group has experienced stages of discrimination and social, cultural, religious, political and economic injustice. This resulted in a backlash from them by strengthening the resistance and spirit of the struggle and also attracted international attention and some countries in Southeast Asia especially Indonesia. This study included to human rights abuses and humiliation emphasizes research questions: How Indonesia Responses in Resolving Rohingya Ethnic Conflicts in Myanmar 20122017. The Urgency of this research is to see how the crime of humanity in Southeast Asia especially in Myanmar occurs systemically and the state participates in it. On the other hand ASEAN does not seem to have a clear sense of responsibility towards the community. Here Then where the response and action of Indonesia seen and observed concretely.
\end{abstract}

Keywords: conflict, human right violations, responsibility to protect, discrimination.

\begin{abstract}
Abstrak
Tulisan ini bertujuan untuk mengetahui dan mendeskripsikan konflik etnis Muslim Rohingya Myanmar dalam kurun waktu lima tahun belakangan ini yang dengan demikian dapat diperoleh temuan-temuan informatif yang dapat memberikan solusi konkrit bagi berakhirnya konflik di Myanmar serta untuk menggambarkan respon Indonesia dalam menyelesaikan konflik etnis ini. Bahwa penelitian ini menggunakan Konsep Responsibility to Protect (R2P), Konsep Pelanggaran HAM yang mana kelompok minoritas muslim Rohingnya telah mengalami tahapan respresi, penderitaan diskriminasi dan ketidakadilan secara sosial-budaya,agama, politik dan ekonomi. Hal itu mengakibatkan timbulnya reaksi balik dari mereka dengan cara memperkuat resistensi dan semangat perjuangannya dan juga mengundang perhatian internasional dan beberapa Negara di kawasan Asia Tenggara utamanya Indonesia. Penelitian ini yang bernafaskan pelanggaran HAM dan penistaan terhadap kemanusiaan menitikberatkan pertanyaan penelitian yaitu: Bagaimana Respon Indonesia dalam menyelesaikan konflik etnis Rohingya di Myanmar 2012-2017.Adapun Urgensi dari penelitian ini adalah untuk melihat betapa kejahatan kemanusian di Asia Tenggara khususnya di Myammar terjadi secara sistemik dan negara ikut andil di dalamnya. Disisi lain Asean sepertinya tidak mempunyai rasa tanggung jawab yang jelas terhadap
\end{abstract}

FOKUS : Jurnal Kajian Keislaman dan Kemasyarakatan vol. 2, no. 2, 2017 P3M Sekolah Tinggi Agama Islam Negeri (STAIN) Curup - Bengkulu Available online: http://journal.staincurup.ac.id/index.php/JF p-ISSN 2548-334X, e-ISSN 2548-3358 
Hendra : Indonesia dan Responsibility To Protect Etnis Muslim Rohingnya | 107 komunitasnya. Lalu disinilah respon dan tindakan Indonesia dilihat dan dicermati secara kongkrit.

Kata Kunci: konflik Pelanggaran HAM, responsibility to protect, diskriminasi.

\section{PENDAHULUAN}

Penindasan terhadap Rohingya di Myanmar 2016-2017 adalah tindakan kekerasan militer yang berlangsung oleh angkatan bersenjata dan kepolisian Myanmar terhadap Muslim Rohingya di Negara Bagian Rakhine di wilayah barat laut negara itu. ${ }^{1}$

Tindakan keras militer terhadap orang Rohingya mengundang kecaman dari Perserikatan Bangsa-Bangsa, kelompok hak asasi manusia Amnesty International, Departemen Luar Negeri Amerika Serikat, dan pemerintah Indonesia dan Negara-negara lainnya. Kepala pemerintahan de facto Aung San Suu Kyi secara khusus telah dikritik karena tidak bertindak dan diam atas masalah ini dan melakukan sedikit tindakan untuk mencegah pelanggaran militer.

Myanmar kembali tersudut atas kekerasan terhadap etnik minoritas muslim Rohingya. Tentara dan kekuatan militer Myanmar terlibat dalam kekerasan terhadap etnik minoritas itu. Militer Myanmar telah membunuh, memperkosa, dan mendorong pembantaian massal terhadap etnik muslim Rohingya dalam bentrokan di Rakhine. Keadaan ini membuktikan bahwa pasukan keamanan Myanmar telah gagal untuk melindungi warga Rakhine dan Rohingya dari kekerasan satu sama lain dan bahkan kemudian mendukung kekerasan dan diskriminasi terhadap etnis Rohingya. Pemerintah Myanmar tidak mampu melaksanakan komitmen mereka untuk mengakhiri kekerasan terhadap etnik minoritas. Tentara hanya berdiam diri ketika komunitas Buddha Rakhine menyerang dan meratakan desa-desa etnis muslim Rohingya dalam serangkaian pembantaian yang terjadi pada akhir Mei 2012 hingga tahun 2017.

Berdasarkan fakta itu, Amnesty Internasional menyatakan populasi Rohingya telah menjadi target untuk dikerdilkan hingga diusir. Beberapa kekerasan bahkan dilakukan aparat keamanan dengan tangan

\footnotetext{
${ }^{1}$ https://id.wikipedia.org/wiki/Penindasan_terhadap_Rohingya_di_Myanmar_2016\%E2 \%80\%932017 diakses 2 November 2017
} 
108| Fokus : Jurnal Kajian Keislaman dan Kemasyarakatan, Vol.2, No. 02, Des 2017

mereka sendiri bekerjasama dengan beberapa kelompok Buddha Rakhine dan pemerintah terkesan hanya menutup mata atas kasus-kasus tersebut.

Khusus (etnik muslim) Rohingya, meskipun perhatian internasional seolah-olah baru saat ini bermunculan, masalah ini sebenarnya sudah lama diperhatikan sejak tahun 2010. Penanganan masalah Rohingya seperti halnya penanganan etnik Myanmar lainnya merupakan satu kesatuan dari proses reformasi dan demokratisasi di Myanmar. $^{2}$

Pemerintah Myanmar menolak mempertimbangkan etnis Rohingya sebagai warganya dan mengklasifikasikan mereka sebagai imigran ilegal dari Bangladesh. Sebaliknya, pemerintah Bangladesh menolak menganggap warga Rohingya sebagai bagian dari warga mereka dan lebih condong mengikuti pandangan PBB yang menyatakan Rohingya sebagai etnik paling tertindas yang berasal dari Myanmar. Perdana Menteri Sheikh Hasina ${ }^{3}$ pun menegaskan negerinya tidak dapat mengakomodasi pengungsi Rohingya ke negaranya. ${ }^{4}$

Gelombang konflik komunal yang terjadi di Myanmar sejak tahun 2012-2017 yang menjadikan kelompok muslim ini seperti gerombolan manusia perahu menjadi perhatian serius Presiden Soesilo Bambang Yudhoyono dan Presiden Jokowi tentunya. Hal tersebut berpotensi mengganggu stabilitas keamanan kawasan dan persahabatan negaranegara anggota ASEAN.

Dalam banyak literatur dinyatakan bahwa Responsibility to Protect (R2P) muncul sebagai respon terhadap kegagalan konsep human intervention menyelesaikan konflik kemanusiaan dan ketidakmampuannya untuk menggalang dukungan internasional. Permasalahan yang mendasar adalah karena dalam pelaksanaan human intervention selalu dihadapkan dengan berbagai konflik kepentingan dari negara-negara tertentu, sehingga kerap kali dilakukan tanpa mandat dan legalitas. Akibatnya humanitarian intervention selalu memunculkan

\footnotetext{
2 Dika Dania Kardi, "Militer Terlibat Pembantaian" Kompas Edisi 27 Juli 2014 diakses 2 November 2017

${ }^{3}$ BBC World-detik News PM Bangladesh: Myanmar Harus Terima Kembali Pengungsi Rohingya

${ }^{4}$ CNN Indonesia Indonesia Bangladesh Paksa Puluhan Rohingya Pulang ke Myanmar
} 
Hendra : Indonesia dan Responsibility To Protect Etnis Muslim Rohingnya | 109 kontroversi, baik ketika intervensi tidak dilakukan maupun ketika intervensi dilakukan. Sejarah mencatat bahwa intervensi kemanusiaan yang terjadi seperti intervensi India di Pakistan Timur, Vietnam di Kamboja dan NATO di Kosovo, selain tidak mendapat mandat dari DK PBB, juga mencederai prinsip non-intervention dalam pasal 2 (4) Piagam PBB. Oleh karena itu, intervensi-intervensi tersebut dipandang sebagai illegal dan hanya menunjukan arogansi kekuatan negara-negara besar yang menginjak kedaulatan negara-negara yang lemah. ${ }^{5}$

Tidak berbeda dengan humanitarian intervention, R2P tidak memandang kedaulatan sebagai suatu yang absolut dalam dunia yang interdependen. Kedua doktrin tersebut membenarkan atau memandang perlu adanya campur tangan asing apabila negara tertentu dianggap tidak mampu atau gagal menghentikan kejahatan terhadap kemanusiaan dan pelanggaran HAM berat. R2P menggeser doktrin "hak" menjadi "kewajiban" negara dan masyarakat internasional menjamin suatu perlindungan terhadap setiap individu.

Namun berbeda dengan konsep humanitarian intervantion, R2P mengedepankan kewajiban negara, baik secara nasional maupun sebagai bagian dari masyarakat internasional dalam memberikan perlindungan dasar terhadap setiap individu yaitu sovereignty as responsibility. Berdasarkan prinsip tersebut, dalam praktek bernegara, suatu pemerintahan nasional yang berkedaulatan mengemban setidaknya tiga tanggung jawab penting, yaitu pertama bertanggung jawab melaksanakan fungsi-fungsi perlindungan terhadap keselamatan dan kehidupan dari warganegaranya dan menjamin kesejahteraan warganya. Kedua, pemerintah nasional bertanggung jawab terhadap warganegaranya dan masyarakat internasional melalui keanggotaannya di PBB. Ketiga, bahwa pelaksana pemerintahan bertanggung jawab terhadap tindakan dan kebijakan yang diambilnya. ${ }^{6}$

\footnotetext{
5 Thomas M. Frank, "Interpretation and Change in the Law of Humanitarian Intervention". In J.L. Holgrefe and Robert O. Keohane (eds), Humanitarian Intervantion: Ethical, Legal, dan Political Dillems, Cambridge University Press,2007. Hal. 204-31.

${ }^{6}$ ICISS, Report of the International Commision on Intervention and State Sovreignty, 2001, hal. 13
} 
110| Fokus : Jurnal Kajian Keislaman dan Kemasyarakatan, Vol.2, No. 02, Des 2017

Dalam the 2005 Summit Outcome menunjukan peran krusial PBB dalam akan konsep R2P yang tertuang didalamnya mencakup tiga pilar yaitu: ${ }^{7}$

a) The protection responsibility of state atau kewajiban negara untuk menjamin perlindungan bagi semua individu yang berada di dalam wilayah kedaulatannya dari pembunuhan massal (genocide), kejahatan perang (war crime), kejahatan terhadap kemanusiaan (crimes against humanity) dan pembersihan etnis (ethnic cleansing).

b) The International assistance and capacity building, yaitu komitmen masyarakat internasional untuk membantu negara-negara yang membutuhkan dalam melaksanakan kewajibannya.

c) Timely and decisive response atau respon kolektif masyarakat internasional in timely dan decisive manner terhadap ketidakmampuan suatu negara dalam memenuhi kewajibannya memberikan perlindungan tersebut.

Kewajiban setiap negara sebagaimana yang disebutkan dalam pilar satu bahwa:

Each individual state has the responsibility to protect its populations from genocide, war crimes, crimes against humanity and ethnic cleansing. This responsibility entails the prevention of such crimes, including their incitement, through appropriate and necessary means... maknanya adalah kewajiban negara untuk melindungi warganya dari genosida, kejahatan perang, kejahatan kemanusiaan termasuk dalam international customary law yang sifatnya compelling.

“...The international community should, as appropriate, enchourage and help States to exercise this responsibility and support the UN in establishing an early warning capacity... also intended to commit ourselves, as necessary and appropriate to helping States build capacity to protect their populations from genocide, war crimes, ethnic cleansing, and crimes against humanity and assisting those which are under stress before crises and conflicts break out."

\footnotetext{
${ }^{7}$ Paragraf 138 dan 139, The 2005 Summit Outcome, UN General Assembly No. A/60/I, 2005
} 
Hendra : Indonesia dan Responsibility To Protect Etnis Muslim Rohingnya | 111

Tentunya pilar kedua R2P menekankan respon dan peran aktif masyarakat internasional mendukung dan mendorong upaya negara tertentu dalam memenuhi kewajibannya tersebut melalui kerangka peningkatan kapasitas dan berbagai bantuan lainnya. Disamping itu, pilar kedua merupakan tindakan preventif terhadap kemungkinan terjadinya pelanggaran HAM berat atau kejahatan kemanusiaan.

"... to take collective action, in timely and decesive manner, through the security council, ... on a case basis and in cooperation with relevant regional organisations as appropriate, ... [if only] peaceful means [are] inadequate and national authorities are manifestly failing to protect their populations from genocide, war crimes, ethnic cleansing, and crimes against humaity..." 8

Bahwa respon dan peran aktif masyarakat internasional mendukung dan mendorong upaya negara tertentu dalam memenuhi kewajibannya tersebut melalui kerangka peningkatan kapasitas dan berbagai bantuan lainnya. Disamping itu, pilar kedua merupakan tindakan preventif terhadap kemungkinan terjadinya pelanggaran HAM berat atau kejahatan kemanusiaan adalah makna penting dari pilar ketiga.

Adapun Konsep Pelanggaran HAM merupakan tindakan pelanggaran kemanusiaan baik dilakukan oleh individu maupun oleh institusi negara atau institusi lainnya terhadap hak asasi individu lain tanpa ada dasar atau alasan yuridis dan alasan rasional yang menjadi pijakanya. Pelanggaran HAM dikategorikan dalam dua jenis, yaitu : ${ }^{9}$

A. Kasus pelanggaran HAM yang bersifat berat, meliputi :

1. Pembunuhan masal (genosida) adalah setiap perbuatan yang dilakukan dengan maksud untuk menghancurkan atau memusnahkan seluruh atau sebagian kelompok bangsa, ras, etnis, dan agama dengan cara melakukan tindakan kekerasan

2. Kejahatan kemanusiaan adalah suatu perbuatan yang dilakukan berupa serangan yang ditujukan secara

\footnotetext{
${ }^{8}$ Bebeb A.K Djundjunan dan Rizal Wirakara, Manusia Perahu Rohingya: Tantangan Penegakan HAM di ASEAN, dalam Jurnal Opini Juris Volume 61 Oktober 2009, Hal. 48

9 Bayu Wahyudi, http://balines-cerita.blogspot.com/2013/08/pelanggaran-hak-asasimanusia-ham_9.html. di akses pada tanggal 2 November 2017
} 
112| Fokus : Jurnal Kajian Keislaman dan Kemasyarakatan, Vol.2, No. 02, Des 2017

langsung terhadap penduduk sipil seperti pengusiran penduduk secara paksa, pembunuhan, penyiksaan, perbudakkan dan lain-lain.

B. Kasus pelanggaran HAM yang biasa, meliputi :

1. Pemukulan

2. Penganiayaan

3. Pencemaran nama baik

4. Menghalangi orang untuk mengekspresikan pendapatnya

5. Menghilangkan nyawa orang lain

Hal yang paling mendasar dalam makalah ini adalah adanya komparasi kebijakan yang dilakukan oleh kedua Presiden Republik Indonesia yaitu Presiden Soesilo Bambang Yudhoyono dan Jokowi dalam membela kemanusian yang terjadi atas pelanggaran HAM etnis Muslim Rohingnya. Pertanyaan penelitian dalam tulisan ini adalah : Bagaimana respon Indonesia terhadap konflik etnis Rohingnya Myanmar 2012-2017.

Penelitian ini bertujuan untuk Mengetahui konflik etnis Rohingya di Myanmar dalam kurun waktu 2012-2017 dan memperoleh temuantemuan informatif yang dapat memberikan solusi konkrit bagi berakhirnya konflik di Myanmar dan untuk menganalisa respon Indonesia terhadap konflik etnis Rohingnya melalui konsep Responsibility To Protect .

Penelitian ini menggunakan metode kualitatif ${ }^{10}$ yang bertujuan mendskripsikan dan menggambarkan secara sistematis, faktual dan akurat mengenai fakta-fakta, sifat-sifat serta hubungan antar fenomena yang diselidiki dengan melakukan pencarian fakta dengan interprestasi yang tepat. Penelitian deskriptif menghantar penulis untuk dapat mempelajari masalah-masalah dalam masyarakat, serta tata cara yang berlaku dalam masyarakat serta situasi-situasi tertentu, termasuk tentang hubungan, kegiatan-kegiatan, sikap-sikap, pandangan-pandangan, serta proses-proses yang sedang berlangsung dan pengaruh-pengaruh dari suatu fenomena.

Adapun bentuk penelitian adalah studi kepustakaan atau library research, dimana pengumpulan data dilakukan melalui metode kepustakaan yaitu suatu metode pengumpulan data melalui penelitian

\footnotetext{
${ }^{10}$ Moh.Nazir, Ph.D, Metode Penelitian, Ghalia Indonesia, Bogor, 2009. Hal 54-55
} 
Hendra : Indonesia dan Responsibility To Protect Etnis Muslim Rohingnya | 113 kepustakaan yang berupa buku-buku, majalah, bahan bacaan lainnya yang berkaitan dengan pokok permasalahan yang dibahas oleh penulis.

\section{HASIL DAN PEMBAHASAN}

\section{A. Eksistensi Etnis Rohingya}

Etnis Rohingya telah mendiami dua kota di utara negara bagian Rakhine, yang dulu dikenal dengan nama Arakan. Wilayah bagian barat Myanmar sejak abad ke-7 Masehi. Saat ini masih terdapat sekitar 600.000 orang Rohingya yang tinggal di Myanmar. Etnis Rohingya secara fisik, bahasa dan budaya lebih mendekati bangsa Asia Selatan, dan sebagian dari mereka adalah keturunan Arab, Persia, dan Pathan dan yang jelas mereka secara paras mirip dengan asia selatan pada umumnya

Selama bertahun-tahun mereka mendapatkan perlakuan buruk dan diskriminatif dari Pemerintahan Myanmar, terlebih lagi paksa operasi Militer King Dragon, ${ }^{11}$ yang telah memaksa mereka mengungsi ke Bangladesh. Menurut data Amnesti Internasional pada periode 19911992, kurang lebih 250 ribu orang Rohingya mengungsi dan memasuki wilayah Bangladesh. Sedangkan menurut data UNHCR. Saat ini terdapat sekitar 28 ribu orang Rohingya yang tinggal di kamp-kamp pengungsi Bangladesh. Ironisnya etnis muslim Rohingya tersebut tidak diakui baik oleh Myanmar maupun Bangladesh sebagai warganya. Pemerintahan Myanmar menganggap orang Rohingya sebagai orang Bengali (Bangladesh) yang tinggal di Myanmar. Pemerintahan Junta Militer Myanmar menyatakan bahwa sekalipun mereka tinggal di Arakan, Myanmar, tetapi etnis Rohingya bukanlah rakyat Myanmar dan tidak termasuk dalam salah satu dari 135 kelompok etnis yang tergabung dalam Uni Myanmar. Pemerintahan Myanmar juga tidak mengakui kewarganegaraan mereka. Sehingga dapat dikatakan bahwa etnis Rohingya ini adalah orang-orang tanpa kewarganegaraan atau stateless ${ }^{12}$.

11 Pada tahun 1978 Pemerintah Myanmar dibawah kepemimpinan Jenderal Ne Win melakukan operasi militer King Dragon Di Negara Bagian Rakhine (Arakan) dalam upaya membrantas para mujahidin di wilayah tersebut. Namun, operasi militer tersebut juga berdampak pada masyarakat muslim lainnya, terutama dari etnis Rohingya.

${ }_{12}$ Orang tanpa kewarganegaraan yang mengakibatkan dirinya,bukan menjadi warga dunia pada hakikatnya dan dengan demikian Negara manapun juga merasa berkeberatan dengan dengannya untuk ditampung atau diberikan suaka politik. 
Menurut Amnesti Internasional, orang Rohingya telah mengalami penderitaan yang cukup panjang akibat pelanggaran HAM yang dilakukan oleh pemerintahan Junta Myanmar. Kebebasan orang Rohingya sangat dibatasi, mayoritas dari mereka tidak diakui kewarganegaraannya. Mereka hanya sedikit dan bahkan tidak diberikan hak kepemilikan atas tanah dan rumah serta dipekerjakan pembangunan infrastruktur di Myanmar. Perlakuan diskriminatif tersebut telah memaksa mereka memilih untuk menjadi manusia perahu dan meninggalkan Myanmar untuk mencari keamanan dan penghidupan yang lebih baik di negara lain. Negara-negara yang menjadi tempat transit dan tujuan mereka antara lain adalah Bangladesh Malaysia, Pakistan, Saudi Arabia, Thailand, Indonesia, Australia.

\section{B. Penyebab Terjadinya Konflik Etnis Rohingya}

Myanmar merupakan sebuah negara dengan tingkat keragaman etnis yang tinggi yaitu sebanyak 135 etnis mendiami kawasan ini. Namun, warga Rohingya etnis Bengali tidak diakui oleh pemerintah junta militer sebagai warga negara sehingga mereka sering mengalami tindak diskriminasi. Kebijakan junta militer yang bersikap represif dan anarkis terhadap etnis Rohingya mulai terlihat secara nyata sejak operasi Naga Min tahun 1978. Ne Win melancarkan Operasi Raja Naga yaitu operasi militer dalam skala besar di Arakan, operasi ini ditujukan sebagai dalih untuk membasmi kelompok Mujahidin yang dituduh melakukan upaya separatis di wilayah utara Arakan. Warga Rohingya banyak yang mengalami penyiksaan, penangkapan sewenang-wenang, dan pembunuhan massal. Mereka dituduh berafiliasi dengan para pemberontak Mujahidin yang ingin mendirikan negara Islam di daerah Mayu, Rakhine utara berbatasan dengan Bangladesh. Banyak warga Rohingya terutama etnis Bengali yang melarikan diri ke Bangladesh untuk berlindung dari operasi militer tersebut.

Sejak peristiwa itulah, warga Rohingya dianggap sebagai imigran gelap. Mereka tidak memiliki kartu tanda penduduk di Myanmar dan hidup sengsara sampai saat ini. Adanya diskriminasi yang dialami oleh warga Rohingya etnis Bengali telah menimbulkan konflik etnis yang berkepanjangan dengan Rakhine. Hal ini dikarenakan junta militer yang 
Hendra : Indonesia dan Responsibility To Protect Etnis Muslim Rohingnya | 115 memutuskan untuk mendirikan sebuah negara bagian di Myanmar Barat dengan memberikan privilege kepada minoritas penduduk Rakhine daripada mayoritas warga Rohingya, padahal terdapat kebijakan bahwa negara bagian terbentuk atas dasar kelompok etnis mayoritas.

Pada tahun 1989, Provinsi Arakan berganti nama menjadi Provinsi Rakhine. Sejak saat itu, sering terjadi konflik antara warga Rohingya etnis Bengali dengan penduduk lokal Rakhine. Konflik etnis Rohingya dan Rakhine tidak lepas dari keterlibatan junta militer, faktor-faktor penyebab konflik etnis dilihat dari faktor struktural yaitu negara lemah dan geografi etnis yang berbatasan langsung dengan India dan Bangladesh, politik berupa diskriminasi institusi politik, elit politik yang dikuasai oleh junta militer dengan adanya kebijakan Burmanisasi dan nasionalisme agama Buddha, diskriminasi ekonomi karena modernisasi Provinsi Rakhine dengan adanya proyek pembangunan infrastruktur pelabuhan Sittwe dan pembangunan eksplorasi gas Shwe yang memaksa junta militer merelokasi penduduk yang tinggal disekitar proyek tepatnya di desa Kyaukpyu bahkan mereka didukung oleh biksu-biksu untuk menyebarkan kebencian terhadap Muslim yang notabene merupakan warga Rohingya yang tinggal di sekitar proyek sehingga konflik antar etnis antara warga Rakhine dengan warga Rohingya etnis Bengali kerap terjadi, sedangkan dari faktor sosial dan budaya karena diskriminasi budaya dan pemahaman sejarah yang kurang tepat dari setiap pandangan masing-masing etnis.

Sementara itu, pemicu secara internal yaitu pemerkosaan Ma Thida Htwe oleh tiga pemuda Rohingya dan pemilahan batas negara yang tidak memperhatikan logika etnis sehingga memutuskan pemerintah junta militer untuk tidak mengakui warga Rohingya etnis Bengali sebagai warga negara Myanmar bahkan pemerintah memutuskan anak Muslim yang lahir di Provinsi Rakhine tidak boleh mendapat akta kelahiran dan tidak diberlakukannya National Registration Cards (NRC) atau kartu penduduk di negara Myanmar bagi penduduk yang memeluk agama Islam. $^{13}$

13 Alif Revolusi, Faktor- Faktor Penyebab Terjadinya Konflik Etnis Rohingya di Myanmar Tahun 2012, di akses pada tanggal 2 November 2017. 


\section{Diskriminasi Terhadap Penduduk Muslim}

Jumlah muslim yang terdapat di Myanmar berkisar 15\% dari penduduk total yang ada sebanyak tujuh juta orang. Kira-kira seperdua dari mereka berasal dari Arakan, yaitu sebuah propinsi di Myanmar bagian barat laut, yang memiliki tapal batas dengan Bangladesh di utara sepanjang $170 \mathrm{~km}$, dan daerah pantai sepanjang $360 \mathrm{~km}$ di sebelah barat, serta tapal batas yang merupakan sebelah timur. Kaum Muslimin di Arakan itu selalu mendapat penindasan yang kejam dari pihak pemeluk agama Buddha, namun mereka tetap mempertahankan identitas keIslaman mereka. Akan tetapi kebanyakan dari kaum Muslimin di sebagian Burma yang lain terutama yang di kota-kota, banyak yang tidak tahan terhadap penindasan itu, dan menyerah sehingga tersedot menjadi bagian dari masyarakat Burma yang beragama Buddha. ${ }^{14}$

2. Diskriminasi Lahan dan Pendapatan Ekonomi

Pada umumnya persoalan ketidakadilan ekonomi sebenarnya telah berlangsung lama di kalangan kelompok minoritas secara etnis ataupun agama, Diskriminasi tersebut didukung oleh beberapa hal: ${ }^{15}$ pertama, pada kenyataanya kelompok tersebut tinggal di wilayah yang terpisah dengan kelompok mayoritas atau kelompok lain; kedua, masih rendahnya fasilitas-fasilitas ekonomi yang mereka miliki; ketiga, pelemahan konflik budaya; atau keempat, diskriminasi yang dilakukan oleh kelompok mayoritas. ${ }^{16}$ Keberadaan semacam itu mengakibatkan mudahnya kecenderungan bahwa mereka semakin teraleniasi menjadi masyarakat peripherial dengan setumpuk masalah ekonomi dan ketidakjelasannya posisinya di masyarakat. Setumpuk persoalan ekonomi, baik sangatlah rendah, dapat pula menjadi pemicu pola-pola hubungan yang buruk tidak hanya minoritas dengan penguasa tetapi juga dengan mayoritas.

3. Tidak Adanya Pengakuan Sebagai Warga Negara Myanmar.

Kebebasan untuk bergerak bagi etnis Rohingya sangat terbatas dan sebagian besar dari mereka tidak diakui status kewarganegraannya

\footnotetext{
${ }^{14}$ H. Lande, Ethnic Conflict, Ethnic Accomodation, and Nation Building in Southeast Asia, Studies in Comparative International Development, Winter 1999; 33 (4): http://web4.infotrac. galegroup.com/itw/infomark

${ }^{15}$ Gurr "Why Minorities Rebel....,", hal. 42-43

${ }^{16}$ Op.cit
} 
Hendra : Indonesia dan Responsibility To Protect Etnis Muslim Rohingnya |117 oleh pemerintahan Myanmar. Mereka juga mengalami berbagai bentuk pemerasan, perpajakan sewenang-wenang, perampasan tanah, pengusiran paksa, penghancuran rumah, dan pembatasan keuangan serta pernikahan. Etnis Rohingya terus digunakan sebagai buruh paksa di jalan-jalan dan kamp militer, meskipun jumlah tenaga kerja paksa di North lebih dari Rakhine State telah menurun selama dekade terakhir.

Apa yang dialami etnis Rohingya sebenarnya juga dialami oleh etnis-etnis minoritas lain yang berada di Myanmar. Laporan Human Right Watch menyebutkan sejak 2004 lebih dari satu juta komunitas minoritas terusir dari desa-desa mereka. Etnis-etnis minoritas yang ikut menderita adalah Kachin, Chin, Mon, Shan yang berdekatan dengan etnis Siam di Thailand. Etnis Rohingya menderita paling parah karena junta yang berkuasa menyatakan bahwa tidak ada kelompok etnis minoritas Rohingya dalam sejarah Myanmar, baik sebelum maupun sesudah kemerdekaan. Etnis minoritas adalah orang Bangladesh yang meninggalkan negaranya untuk kehidupan yang lebih baik. Untuk mendapatkan simpati dari negara-negara Barat mereka mengaku sebagai orang Rohingya dari Myanmar. Perlakuan Junta yang tidak menganggap etnis Rohingya sebagai etnis Myanmar berakibatkan sulitnya etnis Rohingya memperoleh pekerjaan dan sumber lainnya, dan pemaksaan terhadap pemindahaan agama yaitu ke agama Buddha. Perlakuan Junta Militer menyebabkan etnis Rohingya banyak mengungsi ke negara lain dengan menggunakan perahu.

Menurut pernyataan Junta Militer Myanmar ada yang disebutsebut sebagai kelompok etnis minoritas Rohingya dalam sejarah Myanmar adalah tidak benar, pernyataan tersevut terbantahkan dengan fakta sejarah bahwa pada waktu pemerintahan perdana mentri $\mathrm{U} \mathrm{Nu}$ (tahun 1948-1956, 1957-1958, dan 1960-1962) banyak tokoh asal Rohingya berperan dalam pemerintahan seperti Sultan Mahmood yang berasal dari etnis Rohingya misalnya menjadi Menteri Kesehatan.

Konflik yang terjadi di Myanmar bila tidak dapat ditangani dengan baik dapat mengganggu keamanan serta menjadi isu regional karena melibatkan banyak negara di kawasan dan lembaga-lembaga internasional. Oleh karena itu harus dirundingkan untuk mencari solusi yang terbaik agar tidak memunculkan manusia perahu dan menghentikan 
118| Fokus : Jurnal Kajian Keislaman dan Kemasyarakatan, Vol.2, No. 02, Des 2017

terjadinya pelanggaran hak asasi manusia. Penyelesaian masalah menjadi semakin rumit ketika pemerintah Myanmar tidak mau mengakui etnis Rohingya adalah etnis yang berasal dari Bangladesh. ${ }^{17}$

4. Kebebasan Etnis Rohingya dibatasi

Sebenarnya bila dicermati lebih lanjut, konflik kelompok minoritas dengan penguasa, dipengaruhi oleh sikap dan tindakan pemerintahan dapat dilihat dari pola-pola kebijakannya. ${ }^{18}$ Kebijakan pemerintahan terhadap agama dapat disimpulkan menjadi lima pola, yaitu: Pertama, dukungan paksa terhadap suatu agama (enforced support of religion). Agama lebih dijadikan alat oleh pemerintah untuk memenuhi tujuan pemerintah, khususnya digunakan sebagai alat untuk mengintegrasikan masyarakat. Oleh karena itu, bila kelompok minoritas yang selalu menonjolkan identitasnya, akan cenderung dianggap sebagai suatu ancaman bagi negara. Konsep dasar dalam melihat keragaman etnik dan agama untuk mengembangkan nation-building adalah dengan cara menyatukan atau penyeragaman. Artinya, mengeneralisasikan persoalanpersoalan masyarakat atas dasar persamaan yang ada, bukan atas dasar perbedaannya. Kedua, sebatas memberikan dukungan atau motivasi terhadap agama (encouragement of religion) dan tidak sampai pada pemaksaan. Namun konsep ini memiliki kelemahan: (1) dukungan pemerintah cenderung hanya ditujukan pada agama mayoritas saja dengan harapan pengikut agama mayoritas saja dengan harapan pengikut agama mayoritas akan memberikan dukungan kepada pemerintahan yang sedang berlangsung. Bila hal itu yang terjadi, maka memungkinkan terjadinya ketidakadilan dan diskriminasi tehadap agama-agama yang berada dalam posisi minoritas. (2) Dukungan pemerintahan lebih ditujukan kepada agama minoritas, agar dapat mengakomodasikan kepentingan mereka untuk menggapai dukungan politis mereka kepada pemerintah. Bila hal itu yang terjadi, maka seringkali di tingkat masyarakat timbul kecemburuan dari kelompok mayoritas terhadap minoritas dan merupakan

\footnotetext{
17 Myanmar- The Rohingya Minority: Fundamental Rights Denied, Amnesty Internasional, 2004, diakses dari : http;//www.amnesty.org/en/library/info/ASA 16/005/2004

${ }^{18}$ Fred R, von der Mehden, The Political and Social Challenge of the Islamic Revival in Malaysia and Indonesia, dalam The Muslim World: hal.219-233
} 
Hendra : Indonesia dan Responsibility To Protect Etnis Muslim Rohingnya | 119 potensi konflik sosial di antara mereka. Ketiga, sikap netral terhadap agama (neutrality toward religion). Sikap ini menekankan adanya pemisahan antara agama dan negara, bahkan negara tidak ikut campur dengan segala kegiatan keagamaan. Sikap netral terhadap agama adalah seperti apa yang disarankan dan dilakukan oleh Lee Kuan Yew (Singapore) terhadap agama-agama di Singapore. Sebenarnya hal yang sama juga dilakukan oleh San (Myanmar), tetapi pemerintahan yang sedang berkuasa memiliki pandangan yang berbeda. Keempat, beroposisi terhadap suatu kelompok agama (oppositions to a particular religious groups). Pemerintah melakukan sikap oposisi terhadap agama terentu, yang biasanya agama kelompok agama mayoritas, karena ingin memproteksi kelompok mayoritas, karena ingin memproteksi kelompok agama mayoritas dalam perjalanan sosial politik di negaranya. Kelima, beroposisi terhadap agama tertentu, yang biasanya agama kelompok agama mayoritas dalam perjalanan sosial politik di negranya. Kelima, beroposisi terhadap agama sebagai suatu kekuatan dalam masyarakat (Opposition to religion as a force in society).

Kelima pola kebijakan pemerintahan terhadap kelompokkelompok agama tersebut ikut menentukan perkembangan agama di suatu negara. Selain peran pemerintah yang mewarnai perkembangannya, interaksi dengan kelompok-kelompok agama tersebut ikut menentukan perkembangan agama di suatu negara. Selain peran pemerintah yang mewarnai perkembangannya, interaksi dengan kelompok-kelompok lain di masyarakat, seperti dengan kelompok mayoritas dan kelompokkelompok minoritas lainnya juga menentukan dinamika kelompok tersebut.

Apa yang dialami kelompok minoritas muslim di Myanmar terdapat kesamaan pola kebijakan dengan perbedaan implementasinya. Ketika kelompok minoritas minoritas muslim menginginkan eksistensi keislamannya supaya diakui sejajar dengan agama mayoritas dan kelompok minoritas muslim telah mengalami tahapan respresi, penderitaan diskriminasi dan ketidakadilan secara sosial-budaya, politik dan ekonomi. Hal itu mengakibatkan timbulnya reaksi balik dari mereka dengan cara memperkuat resistensi dan semangat perjuangannya. 
Pemerintah Myanmar menolak mempertimbangkan etnik Rohingya sebagai warganya dan mengklasifikasikan mereka sebagai imigran ilegal dari Bangladesh. Sebaliknya, pemerintah Bangladesh menganggap warga Rohingya yang diklasifikasi PBB sebagai etnik paling tertindas berasal dari Myanmar. Perdana Menteri Sheikh Hasina pun menegaskan negerinya tidak dapat mengakomodasi pengungsi Rohingya ke negerinya. ${ }^{19}$

\section{Responsibilty To Protect Indonesia Terhadap Rohingnya}

\section{Kebijakan luar Negeri Indonesia Pada Masa SBY}

Sebagai langkah dan bentuk konkret responsibility protect pada masalah ini maka Repesentasi Negara ini ada pada Presiden SBY dan Jokowi dengan mendesak Pemerintah Myanmar untuk memulihkan keamanan dan memulai proses rehabilitasi, rekonstruksi, dan rekonsiliasi di kawasan yang dilanda konflik komunal tersebut. Kedua Presiden ini juga menyampaikan pentingnya bagi Pemerintah Myanmar untuk memberikan kewarganegaraan kepada etnis Rohingya dan menjamin hakhak sipil etnis Rohingya dan warga Muslim Myanmar secara umum.

Pada kesempatan yang sama, Presiden SBY menyampaikan komitmen Pemerintah Indonesia untuk menyumbangkan US \$ 1 juta untuk proses rehabilitasi, rekonstruksi, dan rekonsiliasi. Presiden SBY juga mendorong beberapa BUMN untuk melakukan investasi di kawasan yang dilanda konflik komunal sebagai langkah rehabilitasi ekonomi. Tawaran Presiden SBY tersebut disambut baik oleh Presiden Myanmar. Pemerintahan Myanmar berusaha memulihkan keamanan di wilayah yang dilanda konflik komunal. Namun demikian, Presiden U Thein Sein mengharapkan terus dukungan Pemerintah Indonesia dalam penyelesaian konflik komunal di Negara Bagian Rakhine dan kota Meikhtila.

Selain membahas penyelesaian konflik komunal, pertemuan bilateral antara Presiden SBY dengan Presiden U Then Sein juga membahas upaya peningkatan kerjasama ekonomi antar kedua negara dan dukungan Indonesia kepada Myanmar yang menjadi ketua ASEAN pada tahun 2014.

\footnotetext{
19 Juanditya Herlambang "Dewan HAM PBB Serukan Militer Myanmar Diselidiki” Kompas Edisi 23 Agustus 2012
} 
Hendra : Indonesia dan Responsibility To Protect Etnis Muslim Rohingnya |121

\section{Kebijakan Luar Negeri Indonesia Pada Masa Jokowi.}

Pada Selasa 29 Agustus 2017 Pemerintah Indonesia melalui Kementerian Luar Negeri. Menyatakan bahwa Indonesia mengecam serangan kelompok bersenjata kepada pos polisi dan fasilitas penampungan pengungsi di Maungtaw Rakhine State pada 25 Agustus 2017 yang telah mengharuskan ratusan orang mengungsi dan menyebabkan putaran kekerasan baru. Indonesia juga menyesalkan jatuhnya korban, baik korban jiwa maupun luka-luka. Indonesia mengharapkan Pemerintah Myanmar segera mengambil langkah-langkah untuk memulihkan keamanan dan memberikan perlindungan kemanusiaan secara inklusif. Indonesia juga mendorong semua pihak segera menghentikan aksi kekerasan, berkontribusi terhadap pemulihan keamanan, serta menghormati hak asasi manusia masyarakat di Rakhine State, termasuk masyarakat Muslim. Situasi di Rahkine State sangat kompleks. Kerja sama semua pemangku kepentingan diperlukan agar perdamaian, keamanan, stabilitas dan pembangunan inklusif, dapat dilakukan di Rakhine State. Situasi yang damai, aman, dan stabil di Myanmar, termasuk di Rakhine State penting untuk mendukung terjaganya stabilitas di ASEAN dan pembangunan yang berkelanjutan di kawasan. Indonesia akan melanjutkan kerja sama dengan Myanmar dalam proses rekonsiliasi, demokratisasi, dan pembangunan inklusif, termasuk upaya implementasi rekomendasi laporan Kofi Annan.

Presiden Joko Widodo (Jokowi) diminta untuk lebih berperan aktif dalam menangani kasus kemanusiaan yang menimpa etnis Rohingya di negara bagian Rakhine, Myanmar. Upaya aktif dalam mendorong kondisi keamanan di Rakhine, akan menjadi catatan penting bagi Indonesia. Adapun Presiden Jokowi dalam jumpa pers yang digelar Minggu, 3 September 2017 menyebut Indonesia berkomitmen untuk membantu mengatasi krisis kemanusiaan yang menimpa kaum Rohingya di Myanmar. "Perlu sebuah aksi nyata, bukan hanya pernyataan, kecaman-kecaman," kata Jokowi dalam keterangan persnya di Istana Merdeka, Jakarta, Minggu, 3 September 2017. Jokowi menyatakan pemerintah berkomitmen untuk terus membantu mengatasi krisis kemanusiaan, bersinergi dengan kekuatan masyarakat sipil di Indonesia, 
serta masyarakat internasional dan menjalin komunikasi intensif dengan berbagai pihak.

Selain itu salah satu kebijakan luar negeri Indonesia yang diterapkan Presiden Jokowi adalah dengan melepas 34 ton bantuan kemanusiaan bagi pengungsi Rohingya di perbatasan MyanmarBangladesh dan itu dilakukan di Base Ops Halim Perdanakusuma, Jakarta Timur menggunakan empat pesawat Hercules. Bantuan ini bukanlah yang terakhir dan pemerintah terus menghimpun bantuan kemanusiaan untuk didistribusikan untuk ratusan ribu pengungsi Rohingya. ${ }^{20}$

Presiden Jokowi telah menugaskan Menteri Luar Negeri Retno LP Marsudi untuk terbang ke Dhaka, Bangladesh. Ini dilakukan untuk menyiapkan bantuan kemanusiaan yang diperlukan pengungsi Rohingya yang berada di Bangladesh. Untuk penanganan kemanusiaan akibat konflik di Rakhine State, pemerintah telah memberikan bantuan makanan dan obat-obatan sebanyak 10 kontainer. Bantuan ini diberikan pada Januari dan Februari lalu. Pemerintah juga telah membangun sekolah di Rakhine State, dan akan segera membangun rumah sakit yang akan dimulai pada Oktober 2017. Sejauh ini Indonesia juga telah menampung pengungsi dan memberikan bantuan yang terbaik.

\section{PENUTUP}

Persoalan ketidakadilan berkehidupan di Myanmar sebenarnya telah berlangsung lama di kalangan kelompok minoritas secara etnis ataupun agama, Diskriminasi tersebut didukung oleh beberapa hal: pertama, pada kenyataanya kelompok tersebut tinggal di wilayah yang terpisah dengan kelompok mayoritas atau kelompok lain; kedua, masih rendahnya fasilitas-fasilitas ekonomi yang mereka miliki; ketiga, pelemahan konflik budaya; atau keempat, diskriminasi yang dilakukan oleh kelompok mayoritas.

Pada dasarnya tanggung jawab kondisi umum sosial dan politik memicu dan melestarikan ketidakadilan tersebut. Hal itu dipengaruhi oleh pola-pola kebijakan sosial-ekonomi dan politik yang berlaku didalam masyarakatnya. Ada tiga jenis pola kebijakan yang berkembang ialah: (1)

\footnotetext{
${ }^{20}$ Kompas.com 13 September
} 
Hendra : Indonesia dan Responsibility To Protect Etnis Muslim Rohingnya |123 modernisasi dan pembangunan di kawasan kelompok minoritas muslim; (2) memberikan otonomi pengelolaan atas kawasan kelompok minoritas muslim; atau (3) sepenuhnya dalam kendali pemerintahan pusat.

Ketidakberpihakan kebijakan pemerintah kepada kelompok minoritas muslim yang pada umumnya miskin, membuat samakin lebarnya jurang kesenjangan dan interaksi hunbunga antara kelompok minoritas muslim dengan mayoritas. Meskipun demikian, hubungan baik biasanya akan tetap terjalin antara muslim dengan kelompok-kelompok lain yang mengalami perlakuan yang sama.

Kebebasan untuk bergerak bagi etnis Rohingya sangat terbatas dan sebagian besar dari mereka tidak diakui status kewarganegraannya oleh pemerintahan Myanmar. Mereka juga mengalami berbagai bentuk pemerasan, perpajakan sewenang-wenang, perampasan tanah, pengusiran paksa, penghancuran rumah, dan pembatasan keuangan serta pernikahan. Etnis Rohingya terus digunakan sebagai buruh paksa di jalan-jalan dan kamp militer, meskipun jumlah tenaga kerja paksa di North lebih dari Rakhine State telah menurun selama dekade terakhir.

Perlakuan Junta yang tidak menganggap etnis Rohingya sebagai etnis Myanmar berakibatkan sulitnya etnis Rohingya memperoleh pekerjaan dan sumber lainnya, dan pemaksaan terhadap pemindahaan agama yaitu ke agama Buddha. Perlakuan Junta Militer menyebabkan etnis Rohingya banyak mengungsi ke negara lain dengan menggunakan perahu selain mendapatkan perhatian Internasional dan Indonesia juga ikut dalam responsibility to protect terhadap muslim yang tertindas ini. 


\section{DAFTAR PUSTAKA}

Acharya, Amitav, 1998, Collective Security and Conflict Management in Shoutheast Asia. Cambridge: Cambridge University

Djunjunan A.K Bebep \&Wirakara Rizal, Manusia Perahu Rohingya: Tantangan Penegakan HAM di ASEAN, dalam Jurnal Opini Juris.

H, Katsumata, 2009, ASEAN and Human Rights: resisting Western Pressure or emulating The West?. "The Pasific Review"

Jackson Robert\&Sorensen George, 2013, Pengantar Studi Hubungan

Internasional, Yogyakarta: Pustaka Pelajar

Levinson David, 1994, Ethnic Relations A Cross-Ensyclopedia. Santa Barbara

Massey Garth, 1999, Ethnic Enclaves and intolerence, Social Forces.

Nazir. Moh, P.hD, 2009, Metode Penelitian. Bogor: Ghalia Indonesia.

Ohta Hiroshi, 2009, The Interlinkage of Climate Secuirity and Human

Security: The convergence on Policy Recruitments. Denmark:

University of Copenhagen.

Oratmangun Djauhari, 2010, ASEAN Selayang Pandang Edisi ke-19.

Jakarta: Sekretariat Direktorat Jendral Kerja Sama ASEAN

$\mathrm{R}$ Fred\&Mahden Der Von, The Political and Social Challange of the

Islamic Revival in Malaysia and Indonesia, dalam the muslim world Rismayati D. Irma, 2009, Manusia Perahu Rohingya: Tantangan Penegakan HAM di ASEAN, dalam jurnal Opini Juris.

Roberts Christopher, 2010, ASEAN's Myanmar Crisis : Challanges to The Pursuit of a Security Community, Singapore: ISAS.

Simth Martin, 1991, Insurgency and The Political of ethnicity. New York

Smith Michael, 2001, "Regional and Regionalism”. New York: Plagrave

Than Mya \& Than Maung Maung Tin, 2001, "ASEAN Enlargement and Myanmar". Singapore: ISAS.

Winarno Budi, 2014, Dinamika Isu-Isu Global Kontemporer. Yogyakarta:

Center of Publishing Service

Yagciougle Dimostenis, 1996, Nation States Etnocultural Minorities. 